Severed nerve ends must be united and dyspnea from throat wounds and depressed fractures should be regarded as surgical emergencies. The immobilization of fractures and search for foreign bodies should be performed as expeditiously as circumstances will allow, until roentgenoscopy is available. Burns, even the most extensive, require picric acid in saturated solution applied with thick layers of gauze kept well moistened. For shock, morphin in half-grain doses, fresh air and physiologic salt solution should be used.

The cause of the greatest number of deaths during naval warfare is the same as during peace, namely, drowning. During the Russo-Japanese war out of a total of 1,891 deaths in the Japanese navy, 1,445 were from drowning. During the engagement off the Falkland Islands, between the British and German fleets, of a total complement of 2,177 on the Scharnhorst, Gineisau, Leipzig, and Nurnberg, the British Admiralty reported "only a few saved." The casualties in the British navy, from the beginning of the war up to March 18, 1915, were 6,668. Most of these were probably from the sinking of Admiral Cradock's fleet off the coasts of Chile, and that of the Cressy, Aboukir, Hoguc, and IIarcke off the European coast.

Submarines, which have proved so efficient in offensive operations during this war, have many elements of danger to their crews. P. A. Surgeon W. H. Halsey, U. S. Navy, from experience with this type of craft, summarizes, to wit:

The dangers from without may be from striking an obstruction when running submerged, striking an obstruction when coming to the surface after a submerged run, diving to too great a depth to be able to acquire sufficient bioyancy to come to the surface, as for example by reason of an abrupt dive, leaks in the water-tight body of the boat and vitiation of the air in the boat due to constant rebreathing and the running of the engines with the batteries on a long submerged run, or when it is impossible to come to the surface.

The dangers from within comprise gasoline poisoning in the gasoline type of boat, which may occur from breathing the fumes of the raw or burned gas and demonstrates itself in various forms of nervous excitation. Wild delirium is frequently seen in gasoline poisoning, and sometimes coma of the profound type. Poisoning by hydrochloric acid gas, from leaks into the battery tanks, may occur. The electrolyte is sulphuric acid and when salt water leaks into it hydrochloric acid gas spreads throngh the boat with great rapidity; men are overcome by the gas almost instantaneously. There is a coughing, choking and gasping for air, and then collapse. Battery explosions sometimes occur, due to the rapid combination of the nascent battery hydrogen with oxygen; this is usually due to defective battery ventilation. Back fire in the gasoline exhaust, sometimes due to ignition of unburned gases in the exhaust, frequently occurs.

Climate and Tuberculosis.-Climate exercises absolutely no influence on the more or less marked frequency of the discase. Tuherculosis takes place just as frequently and its appearance is just as serious among the Esquimaux and the Laplanders as among the negroes of the Congo State or the Kanaki of the New Hebrides. If, generally speaking, these races suffer less than the Europeans, this is exclusively owing to their habit of living together in less numerous groups, and also owing to the nomadic life which some of them habitually lead.--A. Calmette-Lille.

\section{THE RÔlE OF THE NOSE, THROAT AND ACCESSORY SINUSES IN THE ETIOLOGY OF CHRONIC INFECTIOUS ARTHRITIS *}

\author{
ROLAND HAMMOND, M.D. \\ PROVIDENCE, R. I.
}

For many years it has been recognized that perhaps the chief problem to be considered in chronic infectious arthritis is the determination of the etiologic factor within the body. It is reasonable to suppose that if the arthritis be due to some suppurative process, the joint condition should be relieved provided the etiologic factor can be found and removed. In the presence of more than one source of infection, it may require clear judgment and careful analysis of the history and physical findings, in order to determine which factor is responsible for the arthritis in a particular case.

Every organ, every secretion, and nearly every inch of the body has been carefully scrutinized in an attempt to determine the cause of the disease in numerous cases of chronic infectious arthritis. One of the regions of the body which has seemed to offer a fruitful field for such investigation is the domain of the "nose and throat man"-the ears, nose, throat and accessory sinuses.

Many articles have been written of late years, placing emphasis on the importance of these organs in their relation to arthritis. Some of the recent writers have attributed so much importance to this region, as the site of infection in a large number of cases of arthritis, that I was led to undertake the investigation on which this paper is based.

The experience of many workers in this field seems to show an undoubted connection between tonsillitis and arthritis in many cases, especially those acute in onset and character. This study was undertaken to determine, if possible, what percentage of cases of chronic infectious arthritis were found to have coexisting disease of the tonsils, and of the ears, nose and accessory sinuses as well. As would naturally be expected, such examinations would lead to the discovery of disease in the teeth and gums. Whenever possible the dental conditions were studied, their possible relationship to the arthritis analyzed, and proper treatment instituted if found necessary. We also wished to determine the efficacy of treatment by the nose and throat surgeons in these cases, and have endeavored to trace every patient operated on by them, and to ascertain the effect of this treatment on the arthritis.

I wish to state at the outset that I did not shate the opinion of those workers in this field who believe that a recognizable focal infection is present in nearly all cases of chronic infectious arthritis. Nor could $I$ be convinced, from my experience in these cases, that the removal of a focal infection would necessarily cure an arthritis of some months' duration. It is a matter of common experience with those who see a large number of these cases, that a brilliant result is occasionally obtained by the removal of tonsils containing pus pockets, or by the drainage of a suppurating sinus. Similar results are obtained when a focus of infection anywhere in the body is removed. In my experience

* Read before the Section on Orthopedic Surgery at the SixtySixth Annual Session of the American Medical Association, San Francisco, June, 1915. 
such a happy outcome in the case of chronic infectious arthritis is the exception rather than the rule.

Most of the cases of chronic infectious arthritis which have come to the orthopedic clinics of the Rhode Island Hospital and St. Joseph's Hospital during the past two years, in which the etiology was not readily determined, have been referred to the ear, nose and throat departments of these hospitals for examination. This included a majority of the cases of infectious arthritis. Cases in which a gonorrheal infection had immediately preceded the onset of the joint condition were not referred for examination, since the disease was usually limited to one joint, and the connection between the gonorrhea and the arthritis seemed fairly well established.

The cases were not selected in any way, but, as they appeared, were referred for examination and treatment by the nose and throat surgeons when deemed necessary by them. The cases were nearly all polyarticular in distribution, and were the bulk of that interesting and often puzzling group of joint cases, encountered in the daily routine of any adult orthopedic clinic. Cases were referred for examination, even in the absence of any symptoms pointing to disease of the ear, nose, throat or sinuses.

Otherwise these cases were all treated in the routine manner. They were referred to other departments of the hospitals, when necessary, for consultation and treatment, and laboratory and Roentgen investigations were made in nearly every case. In classifying these cases as positive or negative, according as they showed disease of the nose, throat or sinuses, or did not, the opinion of the nose and throat surgeon has been taken as the sole criterion, even in cases in which it seemed to the orthopedic surgeons that some other etiology was probable.

The result of this investigation is shown in Table 1:

TABLE 1.-PREPONDERANCE OF TONSILLAR INFECTION

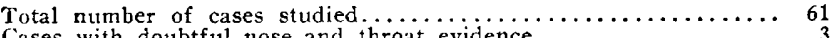
Cases with doubtful nose and throat evidence..................... (ases with negative nose and throat evidence.................

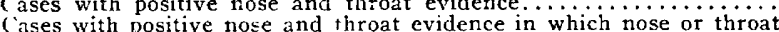

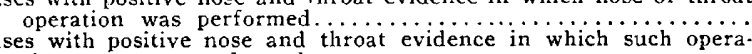

tion was not performed.

In Table 1 the large proportion of cases showing tonsillar infection is noteworthy.

Of the 12 patients operated on, the tonsils were removed in 9 , pockets in the tonsils were opened in 1 , the frontal sinus was drained in 1 , and a deviater? septum corrected in 1 . In two of the cases of tonsillectomy the adenoids were also removed, and in another case the midturbinate was removed to drain the ethmoid cells.

Of the 18 patients not operated on, the tonsils were infected in 12 , there was sinusitis in 3 , otitis media in 1, necrosed teeth in 1, and Riggs' disease in 1 .

The condition of the arthritis following operation for disease in the nose or throat in 12 cases is shown in Table 2:

\section{TABLE 2.-CASES SHOWING POSITIVE NOSE OR THROAT DISEASE AFTER OPERATION

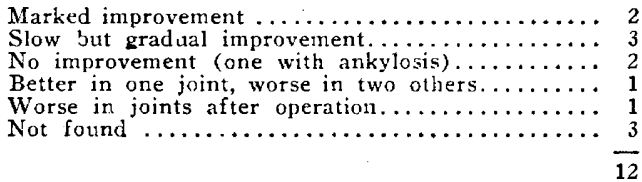

The advice given in 18 cases with positive nose and throat evidence in which operation was not performed is shown in Table 3 :

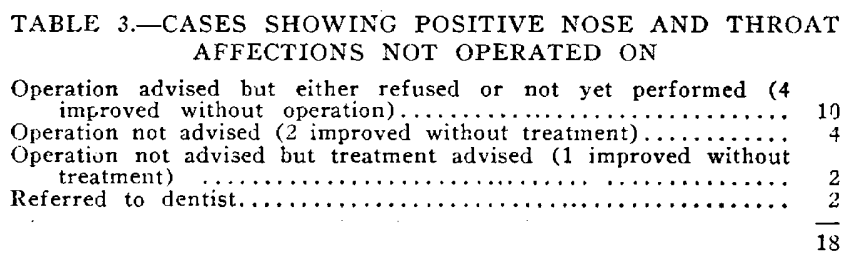

Of the 28 patients with negative nose and throat evidence, 5 had necrotic teeth, 3 had Riggs' disease, and 2 had had arthritis following removal of adenoids and tonsils, in one case six weeks, in the other nine months, after the operation. In the last two cases no connection between the operation and the arthritis is presupposed. In making this report we feel that care should be taken in drawing conclusions from a small number of cases. The difficulties in the way of proper deductions are many. It is a well known fact that deep in its crypts the most innocent appearing tonsil may harbor micro-organisms of a harmful nature. The Streptococcus hemolyticus, which is the special agent found in associated joint lesions, lies in deep chronic abscesses and sealed crypts. Consequently it is very difficult in a doubtful case to determine whether operation should be urged or decried. In the case of an infected sinus, the difficulty of prov-

TABLE 4.--POSITIVE NOSE AND THROAT EVIDENCE IN CASES WITH OPERATION

\begin{tabular}{|c|c|c|c|c|c|c|c|}
\hline & Name & Age & Joints & Duration & $\begin{array}{l}\text { Nose or Throat } \\
\text { Condition }\end{array}$ & Operation & Results \\
\hline E. & $\cdots \cdots$ & 9 & L. knee $\ldots \ldots \ldots \ldots$ & 2 weeks & Tonsils infected, aden & Tonsillectomy ... & Improved \\
\hline i.. & & 2,3 & $\begin{array}{l}\text { L. elbow, r. knee, r. } \\
\text { wrist, l. ankle }\end{array}$ & 5 months & Acute tonsillitis ... & Tonsillectomy $\ldots \ldots$ & $\underset{\text { ment }}{\text { Slight gradual improve- }}$ \\
\hline d:. & & 26 & $\begin{array}{l}\text { Elbows, wrists, hands, } \\
\text { r. knee }\end{array}$ & 7.8 years & $\begin{array}{l}\text { Tonsils infected, aden- } \\
\text { oids present }\end{array}$ & $\begin{array}{l}\text { Tonsillectomy, adenec- } \\
\text { tomy }\end{array}$ & $\begin{array}{l}\text { No improvement (anky- } \\
\text { losis) }\end{array}$ \\
\hline K. & .. & 27 & $\begin{array}{l}\text { Hands, wrists, r. knee, } \\
\text { r. elbow }\end{array}$ & $11 / 4$ years & Tonsils infected ....... & Tonsillectomy $\ldots \ldots \ldots$ & $\begin{array}{l}\text { R. wrist better; } 1 \text {. wrist } \\
\text { and } 1 \text {. elbow worse }\end{array}$ \\
\hline E. & & 28 & $\begin{array}{c}\text { Shoulder, knees, wrists, } \\
\text { ankles }\end{array}$ & 6 months & Tonsils infected . & Tonsillectomy & $\begin{array}{l}\mathrm{Throat} \text { better, joints } \\
\text { worse }\end{array}$ \\
\hline M. & & $\begin{array}{l}24 \\
48\end{array}$ & $\begin{array}{l}\text { Shoulders, knees, feet } \\
\text { L. knee, 1. elbow, r. }\end{array}$ & $\begin{array}{l}6 \text { months } \\
5 \text { years }\end{array}$ & $\begin{array}{l}\text { Deviated septum } \ldots . . . . \\
\text { Tonsils infected, teeth } \\
\text { necrosed }\end{array}$ & $\begin{array}{l}\text { Septum corrected ....... } \\
\text { Tonsillectomy (arthrot- } \\
\text { omy) }\end{array}$ & $\begin{array}{l}\text { Not found } \\
\text { Improved, both throat } \\
\text { and joints }\end{array}$ \\
\hline D. & & 12 & L. hip, hands, r. knee & 3 months & Tonsils infected ....... & Tonsillectomy $\ldots \ldots \ldots$ & $\begin{array}{l}\text { Very slight, gradual im- } \\
\text { provement }\end{array}$ \\
\hline $\begin{array}{l}\text { C. } \\
\text { D. }\end{array}$ & & $\begin{array}{l}21 \\
14\end{array}$ & $\begin{array}{l}\text { Knees, ankles, wrists } \\
\text { L. ankle, knees, hips... }\end{array}$ & 2 months & $\begin{array}{l}\text { Frontal sinusitis } \ldots \ldots \\
\text { Tonsils infected } \ldots \ldots\end{array}$ & $\begin{array}{l}\text { Sinus drained } \\
\text { Tonsillectomy }\end{array}$ & $\begin{array}{l}\text { Not found } \\
\text { Joint condition no better, }\end{array}$ \\
\hline$w$. & & 44 & Shoulders, knees, spine & 4 months & Tonsils infected & Tonsillectomy, adenec- & Slow, gradual improve- \\
\hline G. . & & 42 & Wrists, hips, & 11 years & 'us on midturb & $\begin{array}{l}\text { Turbinate removed, } \\
\text { pocket } \mathrm{s} \text { in tonsils } \\
\text { opened }\end{array}$ & Not found \\
\hline
\end{tabular}


ing its relationship to an existing arthritis is even greater.

It would have been profitable to have investigated other focal sources of infection in these joint cases, such as necrotic teeth, Riggs' disease, lesions of the genito-urinary and gastro-intestinal tracts, gallbladder and other infections. Since the study was limited to the nose, throat and accessory sinuses, however, the conclusions must be based on a study of diseases of those organs.

The results of operative treatment in these cases were, on the whole, not encouraging. The removal teeth or Riggs' disease. Which factor in such a case shall be considered the responsible cause? The removal of one or all of these foci may have no beneficial effect on the arthritis, and we may find that absorption from the gastro-intestinal tract, or some other source, is the real cause.

Our experience has shown that the greatest benefit in these cases is to be expected from stimulating measures tending to build up the general health of the patient, trusting to later improvement in the local joint conditions as the patient responded to treatment. 266 Benefit Street.

TABLE 5.-POSITIVE NOSE AND THROAT EVIDENCE IN CASES WITHOUT OPERATION

\begin{tabular}{|c|c|c|c|c|c|c|}
\hline Name & Age & Joints & Duration & $\begin{array}{c}\text { Nose or Throat } \\
\text { Condition }\end{array}$ & Operation Advised & Results \\
\hline $\begin{array}{ll}\text { (i. } & \cdots \\
J & \cdots\end{array}$ & $\begin{array}{l}.35 \\
+8\end{array}$ & $\begin{array}{l}\text { Knees, ankles .......... } \\
\text { Shoulders, knees, hips, }\end{array}$ & $\begin{array}{l}3 \text { weeks } \\
5 \text { months }\end{array}$ & $\begin{array}{l}\text { Frontal sinusitis } \ldots \ldots \ldots \\
\text { Left otitis media...... }\end{array}$ & $\begin{array}{l}\text { None } \ldots \\
\text { None } \ldots\end{array}$ & $\begin{array}{l}\text { Not found } \\
\text { Improved }\end{array}$ \\
\hline $\begin{array}{l}\text { D. } \\
\text { D. }\end{array}$ & 12 & $\begin{array}{l}\text { wrists } \\
\text { Knees, r. ankle } \ldots \ldots \ldots \\
\text { Knces, feet } \ldots \ldots \ldots \ldots\end{array}$ & $\begin{array}{l}6 \text { months } \\
4 \text { months }\end{array}$ & $\begin{array}{l}\text { R. tonsil infected..... } \\
\text { Tonsils infected, aden- }\end{array}$ & $\begin{array}{l}\text { Tonsillectomy } \ldots . . . . \\
\text { Tonsillectomy, adenec- }\end{array}$ & $\begin{array}{l}\text { Improved } \\
\text { Improved }\end{array}$ \\
\hline D. . & 54 & R. wrist, r. elbow, r. & 3 months & Tonsils infected & Tonsillectomy & Not found \\
\hline $\begin{array}{l}\text { B. : } \\
\text { V. }\end{array}$ & $\begin{array}{l}34 \\
21\end{array}$ & $\begin{array}{l}\text { Feet, } 1 . \text { knee. } \\
\text { Knees, hip, ankle, hand, }\end{array}$ & 2 months & $\begin{array}{l}\text { Tonsils infected } \\
\text { Tonsils infected }\end{array}$ & $\begin{array}{l}\text { Tonsillectomy } \\
\text { Tonsillectomy }\end{array}$ & $\begin{array}{l}\text { Not found } \\
\text { Not found }\end{array}$ \\
\hline S. & 42 & $\begin{array}{l}\text { Wrist, knee, shoulder, } \\
\text { ankle }\end{array}$ & 3 months & $\begin{array}{l}\text { Mucopus in epipharynx } \\
\text { Riggs' disease }\end{array}$ & Teeth extracted. & No improvement (anky- \\
\hline B. & 45 & $\begin{array}{c}\text { Hands, feet, shoulder, } \\
\text { knees }\end{array}$ & 11 years & $\begin{array}{l}\text { Suppurative ethmoiditis } \\
\text { and polypi }\end{array}$ & Turbinectomy $\ldots$ & $\begin{array}{l}\text { Slight, gradual improve. } \\
\text { ment }\end{array}$ \\
\hline W. $\quad M$. & 26 & R. ankle, r. knee..... & $11 / 2$ years & Necrosed teeth & Referred to dentist.... & Not found \\
\hline H. $\cdots$ & $\begin{array}{l}18 \\
48\end{array}$ & Feet, r. thumb, $r$, knee & 4 months & Pockets in tonsil & $\begin{array}{l}\text { None } \cdots \\
\text { None }\end{array}$ & $\begin{array}{l}\text { Not tound } \\
\text { Improved }\end{array}$ \\
\hline S. & 56 & Wrists, ankles, knees... & 2 year & Tonsils infected $\ldots \ldots$ & Tonsillectomy & Not found \\
\hline K & 38 & $\begin{array}{l}\text { Shoulders, knees, hands, } \\
\text { spine, feet }\end{array}$ & 3 months & Tonsils infected $\ldots \ldots \ldots$ & Tonsillectomy . & Not fo \\
\hline B. B. & 15 & $\begin{array}{l}\text { Knees, feet, wrists, el- } \\
\text { bows, shoulders }\end{array}$ & 4 weeks & $\begin{array}{l}\text { Tonsils infected, aden. } \\
\text { oids present }\end{array}$ & $\begin{array}{l}\text { Tonsillectomy, adenec- } \\
\text { tamy }\end{array}$ & Much improved \\
\hline $\begin{array}{ll}\mathrm{I} . & \cdots \\
\mathrm{W} & \cdots\end{array}$ & $\begin{array}{l}39 \\
24 \\
32\end{array}$ & $\begin{array}{l}\text { Hands, r. hip, r. ankle } \\
\text { Knees, shoulders } 1 \text {.... } \\
\text { Knees, feet, shoulders, } \\
\text { ankles }\end{array}$ & $\begin{array}{l}21 / 2 \text { years } \\
11 / 2 \text { years } \\
6 \text { months }\end{array}$ & $\begin{array}{l}\text { Otitis media, sinusitis. } \\
\text { Tonsils infected . ' } \\
\text { Tonsils infected, } \\
\text { disease }\end{array}$ & $\begin{array}{l}\text { None } \ldots . . . \ldots . . \\
\text { Tonsillectomy } \ldots \\
\text { None........... }\end{array}$ & $\begin{array}{l}\text { Died of periostitis femu: } \\
\text { Not found } \\
\text { Slight, gradual improve- } \\
\text { ment }\end{array}$ \\
\hline
\end{tabular}

of tonsils or the draining of a suppurating sinus have produced marked improvement in the joint conditions in these cases in only a few instances. Often there has been slow, gradual improvement as is seen under routine orthopedic treatment. The general condition of the patient has improved after the nose and throat operation in nearly every case. It seemed as if a load had been removed and the general health was much better.

It is to be remembered that the majority of these cases are chronic in nature, and marked improvement is not reasonably to be expected except with the lapse of considerable time. This is even more true when ankylosis is present.

In most of these cases the damage seems to occur early in the course of the disease. The time for investigation and treatment of a focus is in the early stages or even before the onset of the arthritis. Patients who have had previous attacks and have recovered without permanent damage to the joints should have the focus removed, if it can be discovered, to prevent the recurrence of other attacks. This is especially true in the numerous cases in which attacks of tonsillitis have been followed by arthritis. When permanent damage to the joint structures has occurred, but little improvement may be expected from removal of any focus of infection, beyond the improvement in the general health.

The difficulty lies in determining with certainty that the focus which has been discovered is really the cause of the arthritis. Many cases show diseased tcusils or a suppurating sinus coexistent with carious

\section{THE CLINICAL TYPE OF ARTHRITIS ORIGINATING ABOUT THE} TEETH *

THOMAS B. HARTZELL, M.D., D.M.D.

Research Professor of Mouth Infections, University of Minnesota Medical School

MINNEAPOLIS

The etiology of rheumatism has attained a new position in the last few years, and to Alfred Mantle, consulting physician to the Royal Halifax Infirmary, Harrogate, England, should be credited the first work leading to change of position concerning the etiology of this disease. When he commenced his work, bacteriology was in its infancy. At a meeting of the British Medical Association which was held at Brighton, he read a paper in the section of medicine, presided over by the late Sir William Broadbent, the title being, "The Etiology of Rheumatism Considered from a Bacteriological Point of View,"1 at which time he demonstrated the organisms he had found both macroscopically in culture and microscopically.

Even prior to that time, Mantle had discussed the frequency of rheumatic symptoms in scarlatina." His observations in this paper suggested that the

* Read before the Section on Orthopedic Surgery at the Sixty. Sixth Annual Session of the American Medical Association, San Francisco, June, 1915.

1. Mantle, Alfred: The Etiology of Rheumatism Considered from Bacterial Point of View, Brit. Med. Jour., 1877, i.

2. Mantle: Quart. Med. Jour., quoted by Mantet, Practitioner, London, January, 1912. 